\title{
Sociological study of socio-economic and psychological problems of old age people in Basti Ram kali Multan, Pakistan
}

\author{
Zargul Sulaman $^{* 1}$, Aisha Khan ${ }^{1}$, and Saima Munir ${ }^{1}$ \\ ${ }^{1}$ Department Sociology, The Women University Multan, Pakistan \\ *Corresponding Author: zargulsulaman@gmail.com
}

\begin{abstract}
This study examines the socioeconomic and psychological problems of old age people in the area of Basti Ram Kali Multan. All the aged people 65 to above 85years of age including male and female living in the Basti Ram Kali as the target population of the study. The presented study was consists of quantitative methodology. A sample of 103 aged people was selected from the target area by using convenience sampling technique. The collected data were analyzed by applying descriptive statistics like percentage and frequency. Old age people including $71 \mathrm{male}$ and 32 female were selected through this technique. Online survey questionnaire was used as a tool for data collection. Hypotheses were tested through SPSS software. The results and findings of the whole research show that the old age people are facing various socio-economic and psychological problems. The relationship between the socio-economic and psychological problems are significantly related to the changing structure of families. The nuclear families diminished the joint or extended families concept and had changed the overall norms and values of families by which old age people are facing the problems of less decision making in families, loss of social status, and are broadly suffering from health and psychological issues due to insufficient money.
\end{abstract}

Key Words: Socio-economic Problems (Family type, income, social distancing),

Psychological Problems (Depression, dementia)

\section{Introduction}

Socio-economicsare about a combination of an individual's income, occupation, and social background. Socio-economic background is the key to success and future life prospects.

Psychological problems are conditions that have strange thoughts, feelings, and behaviors. Although challenging, it is important that psychologists and mental health professionals agree on what types of internal experiences and behaviors that create the existence of mental disorders.

Old age is an unpreventable phase of human life, determined by both biological and economic factors. There are three related process of old age physical, mental, and social. It is 
a series of transformation from one set of social roles to another, organized by social order and not by birth. (Mishra,2004).

Old age is divided into four stages; physical, blood, functional and emotional. Physical aging is closely linked with the behavior and changes of the individual natural aging that focuses on changes that take place in the structure and strength of the human body, active aging is when those within the circle interfere to maintain their power in the public sphere; and finally, emotional aging reflects a change in one's lifestyle and attitude depending on one's self-esteem. (Ayranci and Ozdag, 2005).

Many factors are responsible for making this a complex challenge in our planning. Despite being a cohesive community; the decline in extended family programs is evident. This is not just a feeling; but the patriarchal and matriarchal system that allows our elders to decision-making positions has also declined, leaving their standing in society diminished. In addition, with the rapid transformation of extended family programs into nuclear families, older people are being put at risk, as younger and more productive family members take over, placing older people in social and economic dependence positions.

In some societies, the aged people are considered a debt and in traditional communities such as Pakistan the old age people are highly valued and respected. But this traditional distinction regarding respect for the old age people disappears under the changing social and economic conditions. Advancement in Technology ever-changing productivity trends, transformation of economic roles has put members of society in a new strain of adaptability and change in roles and social obligations. Changes in technology and economics have put the pricing system in risk. The situation has left the old age people and the old age people in a state of shock and uncertainty in all parts of the world.

In Pakistan, however, changes in family structures have brought about significant changes in the status and role of older persons in the home affairs sector. These factors work together to exclude them from the margins of society with limited access to their relatives or neighbors, reducing the role of decision-making, restricted structures, travel and the use of abusive language by opposing family members. As a result, they feel uncomfortable and frustrated. The needs of the old age people are not met when the full economic dependence of older people in the family is accompanied by the lack of a comprehensive economic and economic development plan in a country aimed at the well-being of older persons.

Pakistan is a Muslim country and Muslims are true followers of Islam, its values and traditions. Most Pakistanis live in rural areas and practice agriculture. Respect for the elderly is considered to be of great importance to Muslims in the Muslim community and the Holy Quran states that it is an obligation to protect and honor parents, especially when it comes to aging. "And your Lord decreased that you worship none but Him. And that you are dutiful to your parents. If one of them or both of them attain old age in your life, say not to them a word of disrespect, or shout at them but address them in term of honor"(Al Quran:17:23).

These instructions apply to elderly and general parents. Here is another verse with a clear command "And lower unto them the wing of humility, and of mercy, and say: My Lord, be kind to them as they raised me up" (Al Quran: 17:24). 
Holy Prophet (PBUH) said “one who does not treat our younger's with affection and elders with respect, is not from us "This powerful recommendation of the Holy Prophet to honor the elderly has a profound effect on Muslim followers. Pakistani society is Muslim and follows its precepts. Traditionally, Pakistani society maintains high regard for the elderly. Yet increasing contact with western societies, the influence of technology, the global media campaign, and the escalation of the economic downturn have diminished this feature of Pakistani society. Rising inflation, demand for officials up to $20 \%$ and lower inflation rates, and stressful economic conditions are contributing to the needs of older people. (Gulzar, 2008)

Aging is a time when everyone depends on each other for each issue, Physiologists said, older people behave like children, older people need care and attention, if they do not achieve their desirable things they become sad and lose their health. Aging age of 60 years and older is increasing daily in the world, the cause of fewer deaths, life expectancy has increased. The number of adults is about (605 million) in the world today and raise this segment of the population by about 2 billion by 2050.In Pakistan old age is viewed as a mark of respect, wisdom, and devotion. This is because of the strong bonds that exist in a shared family system that is enriched by religious values, which respects the status of the adult component. Adults have been seen and seen to invest in their children for the sake of their future. However, because of the influence of western media on our youth it has been observed that these children have left their parents in the grace of God as these children like to be alone and do not like to be with their parents because of their privacy. As a result, this group of older people are at greater risk of poverty in Pakistan, especially in rural areas, with older people being replaced as family heads in the name of love and cultural norms that deprive them of financial independence. Such love and extra protection have led to feelings of loneliness, depression, and depression.(Perna, 2012).

\section{Objectives}

i. To find out the socioeconomic problems of old age people

ii. To explore the psychological problems of old age people

iii. To provide effective measurement in order to eradicate the problems of old age people

\section{Research Methodology}

The nature of study was quantitative. The universe of the study was Basti Ram Kali and the target population was the elderly population of the Basti Ram Kali. Hence, researcher used Convenience sampling technique. Convenience sampling is the basic type of non- probability sampling where the sample is taken from a group of people easy to contact or to reach.A detail research activity was determined on "Sociological study of socio-economic and Psychological problems of old age people in Basti Ram kali Multan” by questionnaire and interview and secondary information collected by online survey (Whats-App, and G-mail). The researcher used convenience sampling technique and collected data from a sample of 103 respondents, consisted of 40 open-ended question. And data were analyzed through 
descriptive analysis. Descriptive analysis is a statistical method for analyzing the percentages and frequencies.

\section{Results and Discussion}

Table 1: Distribution of Gender

\begin{tabular}{|l|l|l|}
\hline Indicators & Frequency & Percentage \\
\hline Male & 71 & 64.0 \\
\hline Female & 32 & 28.8 \\
\hline
\end{tabular}

Table 1 shows that $64 \%$ of the respondents were male and $28.8 \%$ of the respondents were female. Male respondents were higher as compared to female respondents.

Table 2: Distribution of Age-Group

\begin{tabular}{|l|l|l|}
\hline Indicators & Frequency & Percentage \\
\hline $65-70$ & 43 & 38.7 \\
\hline $70-75$ & 28 & 25.2 \\
\hline $75-80$ & 26 & 23.4 \\
\hline $85 \&$ above & 6 & 5.4 \\
\hline
\end{tabular}

Table 2 shows that Majority of the respondents i.e. $38.7 \%$ belonged to $65-70$, While $25.2 \%$ belonged to $70-75 y$ years old, $23.4 \%$ belonged to $75-80$ years old, $5.4 \%$ belonged to 85 and above years old.

Table 3: Distribution of social isolation

\begin{tabular}{|l|l|l|}
\hline \multicolumn{3}{|l|}{ Social isolation is directly related to health, do you agree? } \\
\hline Yes & 71 & 64 \\
\hline No & 32 & 36 \\
\hline
\end{tabular}

Table 3 shows that majority of the respondents i.e. 64\%repondents said yes Social isolation is directly related to health while $36 \%$ respondents said no.

Table 4: Distribution of isolation from society

\begin{tabular}{|c|c|c|}
\hline $\begin{array}{l}\text { Isol } \\
\text { agre }\end{array}$ & loss & d th \\
\hline Yes & 71 & 64 \\
\hline No & 32 & 36 \\
\hline
\end{tabular}

Table 4 shows that majority of the respondents i.e. $64 \%$ were agree that Isolation from society results in the loss of social status, and the loss of freedom, while $32 \%$ respondents were not.

Table 5: Distribution of bonding decrease with family members

\begin{tabular}{|l|l|l|}
\hline \multicolumn{3}{|l|}{ Bonding decrease with family members due to social isolation, do you agree? } \\
\hline Strongly Agree & 7 & 6.3 \\
\hline Agree & 14 & 12.6 \\
\hline Neutral & 0 & 0 \\
\hline
\end{tabular}




\begin{tabular}{|l|l|l|}
\hline Disagree & 50 & 45 \\
\hline Strongly Disagree & 32 & 28.8 \\
\hline
\end{tabular}

Table 5 shows that majority of the respondents i.e. $28.8 \%$ were strongly disagree that bonding decrease with family members due to social isolation, while $45 \%$ were disagree, $12.6 \%$ were agree and $6.3 \%$ respondents were strongly agree.

Table 6: Distribution of family-type

\begin{tabular}{|l|l|l|}
\hline Family Type & Frequency & Percentage \\
\hline Nuclear & 73 & 65.8 \\
\hline Joint family & 19 & 17.1 \\
\hline Extended & 5 & 4.5 \\
\hline Single-Parent family & 6 & 5.4 \\
\hline
\end{tabular}

Table 6 shows that majority of the respondents were i.e. $65.8 \%$ belonged to nuclear family, $17.1 \%$ belonged to joint family, $5.4 \%$ belonged to Single-Parent family while $4.5 \%$ belonged to extended family system

Table 7

: Distribution of financial status

\begin{tabular}{|l|l|l|}
\hline Financial Status & Frequency & Percentage \\
\hline Dependent & 67 & 60.4 \\
\hline Independent & 36 & 32.4 \\
\hline
\end{tabular}

Table 7 shows that majority of the respondents i.e. $60.4 \%$ were dependent, while $32.4 \%$ were independent.

Table 8: Distribution of household income

\begin{tabular}{|l|l|l|}
\hline \multicolumn{2}{|l|}{} \\
\hline Household Income & Frequency & Percentage \\
\hline $5000-10000$ & 20 & 18 \\
\hline $10000-15000$ & 18 & 16.2 \\
\hline $15000-20000$ & 7 & 6.3 \\
\hline Above 20000 & 5 & 52.3 \\
\hline
\end{tabular}

Table 8 shows that majority of the respondents i.e. $18 \%$ were have 5000-10000household income, $16.2 \%$ were have $10-15000,6.3 \%$ have $15-20000$, while $52.3 \%$ were have above 20000.

Table 9: Distribution of source of income

\begin{tabular}{|l|l|l|}
\hline Source of Income & Frequency & Percentage \\
\hline Pension & 18 & 16.2 \\
\hline Through agriculture & 33 & 29.7 \\
\hline Other(Dependent on children) & 32 & 28 \\
\hline Through rent & 20 & 18 \\
\hline
\end{tabular}


Table 9 shows that majority of the respondents i.e. $29.7 \%$ source of income was agriculture, $28 \%$ respondents' source of income was other (dependent on their children) , $18 \%$ respondents'source of income was through rent, while $16.2 \%$ respondents 'income was Pension.

Table 10: Distribution of Children's misbehavior

\begin{tabular}{|l|l|l|}
\hline Cause depression & Frequency & Percentage \\
\hline Yes & 80 & 72.1 \\
\hline No & 23 & 20.7 \\
\hline
\end{tabular}

Table 10 shows that majority of the respondents i.e. $72.1 \%$ were agree that children's misbehavior cause depression, While $20.7 \%$ respondents were not agree.

Table 11: Distribution of loneliness cause like mental disorders

\begin{tabular}{|l|l|l|}
\hline \multicolumn{2}{|l|}{} \\
\hline Psychological problems & Frequency & Percentage \\
\hline Yes & 88 & 79.3 \\
\hline No & 5 & 4.5 \\
\hline Sometimes & 10 & 9 \\
\hline
\end{tabular}

Table 11shows that majority of the respondents i.e.79.3\% were agree loneliness cause of psychological problems like mental disorder, while 9\% were said sometimes and $4.5 \%$ respondents were not agree.

Table 12:Distribution of Mental health issues

\begin{tabular}{|l|l|l|}
\hline Mental health issue & Frequency & Percentage \\
\hline Yes & 60 & 54.1 \\
\hline No & 18 & 16.2 \\
\hline Sometimes & 25 & 22.5 \\
\hline
\end{tabular}

Table 12 shows that majority of the respondents i.e.54.1\% mental health issue among old age people is severely cognitive impairment dementia occur, $22.5 \%$ were said sometimes, and $16.2 \%$ said no.

Table 13:Children ignore them which cause of depression

\begin{tabular}{|l|l|l|}
\hline Ignorance & Frequency & Percentage \\
\hline Yes & 85 & 76.6 \\
\hline No & 5 & 4.5 \\
\hline Sometimes & 13 & 11.7 \\
\hline
\end{tabular}

Table 13 shows that majority of the respondent's i.e.76.6\% said Yes children ignore them which cause of depression, $11.7 \%$ said sometimes, and $4.5 \%$ were said no.

Table 14: Distribution of health status

\begin{tabular}{|l|l|l|}
\hline Health Status & Frequency & Percentage \\
\hline Strongly Agree & 57 & 51.4 \\
\hline Agree & 29 & 26.1 \\
\hline
\end{tabular}




\begin{tabular}{|l|l|l|}
\hline Neutral & 0 & 0 \\
\hline Disagree & 14 & 12.6 \\
\hline Strongly Disagree & 3 & 2.7 \\
\hline
\end{tabular}

Table 14shows that majority of the respondents i.e.51.4\% were strongly agree that regular checkups can maintain health, while $26.1 \%$ were agree, $12,6 \%$ were disagree and $2.7 \%$ were strongly disagree.

Table 15: sing time with their children

\begin{tabular}{|l|l|l|}
\hline Passing time with their children & Frequency & Percentage \\
\hline Yes & 65 & 58.6 \\
\hline No & 38 & 36.8 \\
\hline
\end{tabular}

Table 14shows that majority of the respondents i.e.58.6\%were agree that passing time with their children can reduce depression, while $36.8 \%$ were not.

Table 16: Counseling of old age people can reduce their psychological problems

\begin{tabular}{|l|l|l|}
\hline Response & Frequency & Percentage \\
\hline Yes & 82 & 79.6 \\
\hline No & 21 & 20.3 \\
\hline
\end{tabular}

Table 16 shows that majority of the respondent's i.e.79.6\% counseling of old age people can reduce their psychological problems while, $20.3 \%$ respondents were not agree.

\section{Discussion}

Socio-economic and psychological problems can be removed from society because old age people are important to our health. Children should support their basic needs. Children should give more time and attention to their parents. Children need to involve their parents in the decision-making process. Children should spent time with their parents which can reduce their depression because in old age they feel loneliness. So that's why children need to take care of their parents in all areas of life. Civil society organizations should respect of old age people. NGOs should run campaigns on the importance of family values. Pakistan's printer electronic media should focus on family values and family structure in different content categories Children should not ignore them (older people) should take care of their parents. In this way the social and economic and psychological problems of the elderly can be solved.

\section{Conclusion}

In this society, where I research without being bound by cultural and superstitious rituals, beliefs, values, traditions and customs but I am motivated by radical change in family structure and social structure. The end result of this change in family structure and the change in social structure has created problems for older people. As a researcher, I found that older people are not adjusted to nuclear families. $65.8 \%$ of the population lives in the Nuclear family. Older people face a cluster of problems such as, social status, social media, low level respect, dependency which have memorized them in their lives and loneliness and isolation reigns in their lives because they think society does not know their existence. The economic situation and the state of health are also beyond their control until they have relied on their 
children. $60.4 \%$ of the old age people are dependent on their children and $32.4 \%$ are independent because they earn money from pensions and agriculture, but those older people who are educated and unskilled go to poverty, and committed suicide .In short, older people find it difficult to cope with a stressful and changing society. No such programs are undertaken by the authorities to assist them financially. Older people are educated which is why they do not get a pension and unfortunately have to rely on their children. It has been observed that widows live in isolation, and are often victims of depression.

\section{Acknowledgments}

The authors would like to thank the Editor and Manage team for the support..

\section{References}

(Ayranci, at al., 2005). Old age and its related problems considered from an elderly perspective in a group of Turkish elderly. International Journal of Geriatrics and Gerontology

Anonymous, 1996. Population and ageing in Asia and pacific islands. United Nations Organization's Report, New York, USA.

Ali and Kiani, 2003.Ageing and poverty in Pakistan. Pakistan Institute of Development Economics

Ahmad K and M Hafeez, 2011. Factors affecting social participation of elderly people: A study in Lahore, Pakistan. Journal of Animal and Plant Sciences, 21: 283-289.

Ahmad K, 2011. Older adults' social support and its effect on their everyday selfmaintenance Activities: Findings from the Household Survey of Urban LahorePakistan. South Asian Studies: A Research Journal of South Asian Studies, 26: 37-52. Al Quran: 17: 23. Al Quran: 17: 24.

Ali, R.(2013a). Ageing in Pakistan, A situation analysis. Ministry of Social Welfare and Special Education, Islamabad, Pakistan. Anonymous, 2013b.Economic Survey of Pakistan. Government of Pakistan Islamabad, Pakistan

Mahmood, at al., (2008). Pension and social security schemes in Pakistan: Some policy options (No. 22211). East Asian Bureau of Economic Research

Cowgill DA, 1972. Theory of Aging in Cross-Cultural Perspective. In: Cowgill DA and L Holmes (eds.): Aging and Modernization, Appleton century-crofts, New York, USA.

MansoorHasan (2016). Pakistan lacks policy for its fast growing elderly population. Karachi: Daily Dawn Jan 27, 2016 Retrieved on Jan 27, 2016 Retrieved from http://www.dawn.com/news/1235585 National Coalition for the Elderly (2009). Homelessness among Elderly Persons. Washington: Retrieved on February 10, 2016 Retrieved form http://www.nationalhomeless.org 
(Hagan, at al., 2014). Reducing loneliness amongst older people: a systematic search and narrative review. Aging Mental Health 18, 683-693.Doi: $10.1080 / 13607863.2013 .875122$

Macionis, J., 2012. Sociology. 14th Edn., USA: Pearson Publication.

(Ahmed, at al., 2015). Socio-economic problems of aged citizens in the Punjab: A case study of the districts Faisalabad, Muzaffargarh, and Layyah. Pakistan Journal of Life and Social Sciences, 13(1): 37-41. View at Google Scholar

Cumming, E., 1961. Growing old: The process of disengagement. New York: Basic Books.

(Gulzar, at al., 2008).Socio-economic problems of senior citizen and their adjustment in Punjab, Pakistan. Pakistan Journal of Agricultural Sciences, 45(1): 138-144. View at Google Scholar

Henslin, J., 1990. Sociology: A dawn to earth. 10th Edn., USA: Pearson Publication, USA

Hussain, M.Z., 2014. Socioeconomic status and health inequalities among older people from Bangladeshi ethnic minority group in England. University of Portsmouth, 16(1): 1-10.

Jeyaseelan, M., 2011. A study on aged persons in old age homes of Chennai. Channai, India. Unpublished Doctrol Thesis of Sri Krishnadevaraya Unum] Iversity

Mudege, N.N., and A.C. Ezeh, 2009. Gender, aging, poverty, and health: Survival strategies of older men and women in Nairobi slums. Journal of Aging Studies, 23(4): 245-257. View at Google Scholar | View at Publisher

(Muhammad, at al., 2009). Old age people: A socio-economic view of their problems in Peshawar city. Pakistan. Pakistan Journal of Life and Social Sciences, 7(2): 126130. View at Google Scholar

(Sarfaraz, at al., 2015). Problems faced by senior citizen in contemporary society: Finding from the household survey in Karachi-Pakistan. International Journal of Research in Humanities and Social Studies, 2(11): 27-36.

UN World Population Ageing, 2015.UN, department of economic and social affairs, population division. New York: The United Nations. 